\title{
Scaling Capitalist Class Relations: Commercial Property Development in Tampa, Florida
}

\author{
M. Mark Amen*
}

University of South Florida, School of Interdisciplinary Global Studies, SOC 107, 4202 East Fowler Avenue, Tampa, Florida 33620, USA

\begin{abstract}
Transcalar capitalist networks form around diverse material and human resources located in many places. One purpose is to "lock in" or direct these resources to specific urban commercial property developments. I extend the scope of previous research about the Transnational Capitalist Class (TCC) and Transcalar Territorial Networks (TTNs) to a case study of commercial real estate in Tampa, Florida. Local printed news records are used to trace the evolving status of the Channelside Plaza project since the 1980s. I identify and describe relations among the changing actors, institutions, resources, and legal mechanisms that by mid-2014 allowed one former hedge-fund manager to amass control over the project and 40 acres of land contiguous with it. The case demonstrates that intra-class relations can be contentious when capitalism is in crisis and that the likely elite sources to overcome conflict are financial finesse linked to effective local relations.
\end{abstract}

Keywords: Financial Markets, Urban Land Development, Class Relations.

\section{INTRODUCTION}

In search of new ways to accumulate wealth, the Transnational Capitalist Class (TCC) of transnational corporations, states, technicians and merchants and media consumers (Sklair 1997; 2002; Robinson 2004, 2012; Strune 2013; Van der Pigl 2005) oversaw construction of the global political economy. Although this class is generally assumed to be of one mind about how to pursue wealth through capitalist production and consumption, Bello (2006:1365) found evidence to suggest disunity between the interests on the one side of transnational corporations and the multilateral system of global governance and, on the other side, national economic interests that have led to "growing inter-capitalist and inter-imperialist competition". Others have noted that class tensions emerged among different ethno-national groups as they integrated with the global economy. For instance, Robinson (2012) noted class differences over real material, cultural religious, and social issues during the 1980 s and 1990s when

\begin{abstract}
[t]ransnational fractions of local elites in competition with nationally-oriented fractions vied for, and in many countries around the world won, state power. They utilized that power to push capitalist globalization, to restructure national productive apparatuses and integrate them into the new global production and financial system (351).
\end{abstract}

*Address of correspondence to this author at the University of South Florida, School of Interdisciplinary Global Studies, SOC 107, 4202 East Fowler Avenue, Tampa, Florida 33620, USA; Tel: 813-974-6912;

Fax: 813-9740832; E-mail: amen@usf.edu
Well before these tensions surfaced, the prospect for protracted intra-class conflict was planted. The Euromarket was formed in the mid-1950s when the Soviet Union sold gold to purchase grains with convertible currencies. Their actions, although with subsequent transfers by British multinational companies, created a trans-border private capital investment market outside public regulatory authority at the national or international level. This market grew rapidly when OECD members liberalized capital movements and when developing nations began to borrow OPEC surpluses invested there. The emergence of a financial network of global cities (Sassen 1991) facilitated electronic trade, the amalgamation of stock markets, and the commodification of capital in innovative new forms. The financialization of economies or what Corpataux et al. have called "the primacy of the financial markets in the accumulation of wealth" (2009:316), was in place by the end of the last century.

This ubiquitous, unregulated and opaque market adds a new and autonomous fraction to the TCC. This new wing of capitalism constitutes an untethered financial class in search of ever expanding returns from increasingly mobile and liquid investments that take many commodified forms: mutual funds, hedge funds, forms of venture capital, "hot money", and a myriad of derivative instruments. Robinson (2012) has described this as an "integrated global financial system [that] has replaced the national bank-dominated financial systems of the earlier period...." Yet many scholars either subsume the financial into the other fractions of the TCC or, as in Robinson's work, treat it as "...the hegemonic fraction of capital on a world scale in the 
sense that it imposes its direction on the global economy and it shapes the character of production and social life everywhere." (354).

\section{FINANCIAL MARKETS AND COMMERCIAL REAL ESTATE}

How does such a hegemonic position for private financial markets affect unity among the various fractions of the capitalist class? Local commercial real estate development is one arena in which to document intra-TCC relations. Why? When capital market liberalization became a part of neoliberal policy beginning in the early 1980s, it was only a matter of time before investors throughout the world saw both residential and commercial real estate as good investment opportunities. Linked with Structural Adjustment Policies after 1985, neoliberal prescriptions provided an impetus to the land-grabbing movement (Margulis, McKeon and Borras 2013). The intended and unconsidered consequences from such development exacerbated a number of concerns, including food security (Borras et al. 2009), climate change, water scarcity (Rulli, Saviori and Odorico 2012), and national sovereignty (Sassen 2013). But the Asian real estate market was the first to be destabilized by this deterritoralization. The financial crisis there in 1997-98 was caused by short-term trans-border capital movements - "hot money" - intermediated by Thai banks and encouraged by government-led fixed exchange rates. The disastrous consequences in Asia did not deter the worldwide land-grabbing movement.

In 1960 the United States Congress authorized Real Estate Investment Trusts (REITs) and this opened to all investors, however small, the opportunity to invest in land as a relatively stable "secondary circuit" of capital (Lefebvre 1970; Harvey 1978). However, Gotham (2006) noted that the foundations for this stable investment option began to erode with the emergence of neoliberal policies in the 1980s when "...federal regulations and congressional statutes...attempted to deterritorialize real estate by enmeshing the financing of residential and commercial property within global capital markets." (233) He found that securitization of the commercial mortgage-backed market allowed real estate to be financed in global markets, thereby transforming real estate into a liquid financial asset that is disconnected and "abstracted from local conditions" (233). REITs allow a group of "corporations or trusts that combine the capital of many investors to buy or provide financing for real estate by selling stock" (Szymanski 1993). While real estate is fixed, its global character can be attributed to combining a deregulated global financial system with post-Fordist forces of organizational fragmentation of real estate that have "become more complex, more decentralized, and more standardized...[allowing] capital and the spatial configuration of cities [to] become more integrated" (Bieri 2013:3).

In the case of Swiss pension funds, Corpataux et al. (2009:320) pointed out that financial market investors did not initially gravitate to the "real economy" (manufacturing, agriculture, tourism, real estate). But they found that changes in pension fund investments helped promote investments in new sectors like property. This led the authors to predict that

...as the financial community continues to
develop its own increasingly distinct
investment criteria....we will see that the
finance industry has taken on a life of its
own and is expanding and developing its
hold over the rest of the economy.... new
dynamic of financial expansion, a new
"spatial fix" to quote Harvey (1982)...a
new means ...of resolving capitalism's
inherent crisis tendencies...(321)

What, then, is the impact on TCC unity of abstracting both real estate and its ownership/control from their place-location? This question about TCC unity of purpose warrants three distinct yet inter-related inquiries to make about commercial real estate investments. First, despite the removal of real estate from the confines of place, location may still matter. In what respects might this be the case and for which fractions of the TCC? In his case study of Columbus, Ohio, Wood (2004) found that "local firms embedded within particular metropolitan markets" trumped the "pace and extent of scalar restructuring" that other economic geographers had claimed dissolved the link between local land and local capital. While he acknowledged that the commercial real estate industry "exhibits evidence of globalization, not the least in the financing of development" (137), Wood concluded that the commercial real estate industry persisted in its fragmentation and parochialism. But he also pointed out that not all firms - the corporate component of the TCC - had to be "Columbus" firms to tap into local networks where "the cultural embeddedness of economic and political practices and the local networks through which knowledge and influence are mobilized" (Wood 1999:119). Firms based in Dallas, St. Louis, and Denver had developed sizeable square footage in Columbus. 
This leaves the question of what about "local" matters when concluding commercial real estate development deals. What is meant by "local" if the wellworn local-global dichotomy is suspended? This second line of inquiry is partially prompted by the emergence of a financial market fraction of investors who, independent of their physical location, increasingly consider or are led to commercial real estate ownership as a sound investment strategy. Consider, for instance, the "hot money" that flowed from investors throughout the OECD to Thai real estate developers in the late 1990s. Halbert and Rouanet (2013) addressed the scalar complexity of relations between "foreign" investors and commercial development projects in India. The authors proposed a new concept - transcalar territorial networks (TTNs) "...to explain how resources from multiple horizons are pulled together in a given business property development, from a fixed plot of land to capital allocated in distant investment committee boardrooms." (2013:2) Their case study on business property development in Bangalore included analysis of how a TTN internalizes perceived risks of foreign investors about local conditions in the property markets of the South. TTNs cut across and brought together diverse resources (e.g. finance and human capital) located at multiple levels. Their purpose in doing so was to "lock in" or direct these resources to specific urban commercial property developments. Their success was contingent upon extending this reach to include yet go beyond the nation/international link - the cross border liberalization of movements of real estate investment. They drew in the expertise, contacts, and cultural vagaries at each level. TTNs had the capacity to alleviate concerns of foreign investors by including expertise about institutional rules, legal requirements, and political preferences. Yet the study of investment risks and concerns of "foreigners" leaves unanswered the meaning of "foreigner" in analyzing transcalar relations. If real estate is abstracted from its place and for its investors, then one might consider a New York City property development firm's ownership of commercial real estate in Tampa, Florida to be as "foreign" as a Japanese multinational corporation's ownership of Rockefeller Center in New York City. What is the precise scalar relationship between financial market investments and commercial real estate location?

Who is making decisions about capital investments in commercial real estate transactions? If we put aside how to overcome the risk concerns of potential investors, we are still confronted with an abstract pool of finance capital that underpins real estate deal making. Pension savings are one component of this pool, leading Corpataux et al. (2009) to note that "...several thousand small [pension savings] funds outsource everything because they have no in-house skills and rarely know where their money is invested." (324) This is equally the case with millions of small investors whose savings flow into hedge funds, mutual funds, and REITS that may be invested in commercial real estate. Furthermore, property ownerships are funneled through multiple limited liability corporations and partnerships to diversify risk and hide liability. Owner verification is even more difficult when these legal corporations are established in "offshore" sights.

In the following case study of the Channelside Entertainment District in Tampa, Florida I pursue these lines of inquiry: the significance of "local" relations, the scale at which these relations matter, and the transparency of financial investments in commercial property. The purpose in doing so is to determine how class unity of the TCC fares when a distinct financial fraction is added to the TCC dynamic. In this exploratory study, I construct a historical description of the Tampa Port Authority's efforts to develop the Channel District over a thirty-year period from the 1980s to 2015. The description is based on empirical data found in news media sources. Based on the evidence, I find how intra-class tensions arose and were resolved in three distinct periods of TCC relations. I also identify how finance capital is channeled through a series of interlinked actors that make use of multiple scales to effect the development of a particular commercial investment property. I draw out implications for accounts of class unity and networking and conclude by proposing future research to address shortcomings in the initial study.

\section{CASE CONTEXT}

Tampa is a port city on the Gulf of Mexico (see Map 1). With a city population of 350,000 in a county of 1.3 million and an MSA population of nearly 3 million, it is the "industrial" center of the west coast of Florida and the nineteenth largest metropolitan area in the United States.

The government of the area is decentralized into multiple incorporated cities and counties. With antiquated zoning laws, poor layout, underutilized land in important areas, lack of living amenities, poor transportation, and a diverse and disunited population, 


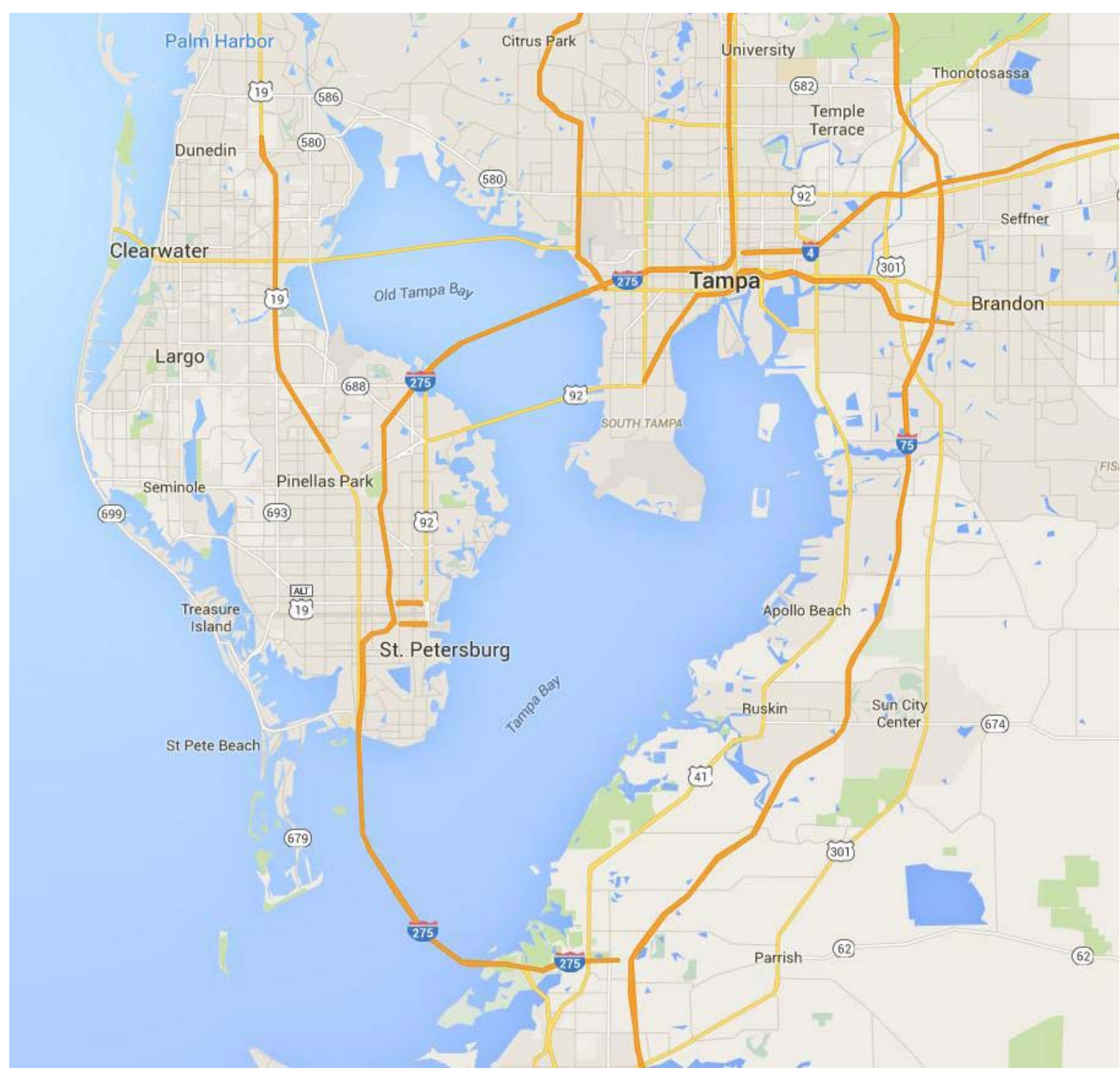

Map 1: Tampa Bay.

Source: https://www.google.com

Tampa has struggled to establish a consensus about the kind of urban area it wants to become. Nevertheless, Tampa has a first-class international airport that is the recipient of numerous awards for its state-of-the-art facilities and is currently undergoing a nearly $\$ 1$ billion upgrade and renovation. It is expanding its international flights and adding domestic nonstop flights within the continental United States. Tampa also has a nationally ranked state higher education institution with an annual budget of over $\$ 1.5$ billion, a student body of over 46,000 , and programs in medicine, public health, nursing, education, arts and sciences, engineering, and business. It is home to three major professional sports teams in football, baseball, and hockey: the Bucs, the Rays, and the Lightning.
The city is undergoing a downtown renovation, including a river-walk that spans the length of the Hillsborough River and construction of high rise apartment buildings intended to expand the downtown residential population. It is part of the second largest $\mathrm{K}$ 12 school system in the United States. Tampa has a history of racism: $63 \%$ of the city population is white; $26 \%$ is African American, and $23 \%$ is Hispanic or Latino (2010 Census data). Ybor City is within the city limits and was founded in the 1880 s by cigar manufacturers who brought immigrants from Cuba, Spain, and Italy to roll millions of cigars annually until the 1929 Depression. Today Ybor City is in revival.

Significant portions of the land in downtown Tampa are owned, managed, and/or developed by a mix of 
public and semi-public institutions. The Port of Tampa Bay is adjacent to Ybor City on its southeastern border and the Channelside district is immediately south of Ybor. The Tampa Port Authority (TPA) is a semi-public entity. The Mayor of Tampa and one County Commissioner serve on a seven-member governing board appointed by Florida's governor. It is the largest port in Florida (and the $6^{\text {th }}$ in the United States) in terms of throughput tonnage (petroleum and phosphate are its leading commodities) and is twenty-five miles from the open waters of the Gulf of Mexico. It services container ships and three cruise lines serving the Caribbean have port of call in Tampa.

The Port is currently undergoing a multi-million dollar renovation so it can serve large container ships passing through a widened Panama Canal scheduled to open in 2016. Ports America operates two container berths, three gantry cranes, and a container terminal. Zim American Integrated Shipping Company provides global connections to the Port. The newly opened I-4 Selmon Expressway Connector allows thousands of trucks a day to pass directly to the Port from the interstate that runs from Daytona Beach on the east coast of Florida through Orlando to Tampa Bay. The port's cruise line future is in jeopardy since the projected size of new cruise ships cannot pass under the Skyway Bridge at the mouth of Tampa Bay were the port leads to the Gulf. The City owns the Convention Center, the David A. Straz Jr. Center for the Performing Arts, and the recently opened Museum of Fine Arts, all of which are not-for-profit corporations.

\section{THE CHANNEL DISTRICT: CHANNELSIDE RETAIL AND ENTERTAINMENT COMPLEX}

Prior to the 1970's, the entire Channel District was owned privately by various shipping companies, private fishermen and warehouse owners. In the 1970s and 1980s, the Port Authority realized the area was in stagnation and needed some revitalization. It created a "Master Development Plan" to develop the area and bought much of the land in the Channel District (Channel District History 2012). The Port's Board hoped to entice passenger cruise lines to the port by making the Channel District more "people friendly. "The Tampa City Council voted to approve the Florida Aquarium on Port Authority land at the Garrison Seaport on August 15, 1992 and the doors opened March 311995.

Tampa's per capita public debt increased nearly sixfold between 1983 and 1993 from $\$ 145$ to $\$ 868$. When the Port-owned Channelside Complex project was first proposed, the city was already heavily leveraged with other development projects: the Convention Center, Performing Arts Center, Centro Ybor, Lowry Park Zoo, and Parking Garages in Ybor City. As in most U.S. cities, Tampa found multiple ways to support the creation of semi-public authorities that could issue bonds for development projects without voter approval. The bond issuing activity of the Port Authority, the Tampa Hillsborough Expressway Authority (THEA) and the Hillsborough County Board of County Commissioners were critical components in the development of the Channel District. The Port's bondissuing activity was largely confined to the Channel District. The Hillsborough County Board of Commissioners occasionally stepped in with a bond issue for projects like the hockey stadium (currently named Amalie Arena) for the Lightning team.

ConAgra Foods, Inc. (\#4 on Map 2) is pertinent to this case because of its strategic location in Channelside. It is a packed foods company headquartered in Omaha, Nebraska. Founded in 1919 and renamed in 1971, the company re-emerged from potential bankruptcy in the 1980 s by buying up a number of prepared food brands (e.g., Banquet Foods, Duncan Hines). It has owned the flour mill, located in the middle of the Channel District since 1938. The mill occupies a key piece of real estate in Downtown Tampa. It operates around the clock, employing 35 people and ships 1.5 million tons of flour daily to bakers in the Southeastern United States and the Caribbean (Thalij 2012). In mid-2003, the Tampa-Hillsborough Expressway Authority purchased some land from the rail freight company CSX in order to connect one street, Meridian Avenue, to the expressway. The terms of the deal stipulated that while CSX would be allowed to continue using the land, ConAgra would have to pay the rent since the rail spur on the land was a specific asset for them. ConAgra and the Authority went to court over the rent and settled in 2006 when ConAgra agreed to pay $\$ 250,000$ a year for the use of the land, with the lease amount increasing to $\$ 375,000$ after nine years (Shopes 2006). In late 2012 and for the first time, ConAgra expressed a willingness to discuss a possible move, but only if the City would build a new plant in Tampa for ConAgra (Thalij 2012). In May 2014 it was renamed Ardent Mills after a Cargill-CHS joint venture combined the operations of ConAgra Mills and Horizon Milling (Kritzer 2014). Since then, negotiations with the city have stalled. 


\section{Stage I - 1995-2005: ORIX Ownership}

The Channelside Retail and Entertainment Complex was launched in the late 1990s when the TPA issued a contract to ORIX Real Estate Equities, a real estate development firm in Chicago, to develop an entertainment and shopping center on the land. It is a subsidiary of ORIX Corporation, a Japanese multinational established in 1964 with a global network that, as of 2012, spanned 35 countries and included corporate financial services, real estate and retail investment operations, and overseas business in aircrafts and shipping. ORIX USA, headquartered in Dallas, Texas and employing over 1,100 people, was established in the 1980s as the commercial leasing subsidiary of ORIX Corporation. It owned $\$ 5$ billion in assets and managed another $\$ 30$ billion of other's assets. It offered services in investment banking, hedge funds, and advised on public and private credit and equity instruments. In the field of real estate asset management ORIX USA created ORIX Capital Markets which acquired and developed commercial real estate. It developed and managed over 16 million square feet of retail, office, industrial and hotel properties valued at over $\$ 2$ billion.

ORIX brought in a local developer, The Hogan-Burt Development Group, to develop and manage the project. The two men behind Hogan-Burt, Mike Hogan and Jim Burt II, were both well connected in the Tampa-area development network. They merged in September 1995, hoping to gain advantage over larger firms by exploiting their respective specialties in office spaces and warehouses (Gruss 1995). Mike Hogan had always been involved in real estate. Right after graduating college, he started a home building company in Atlanta that failed in 1975. He then came to Tampa and worked for different Tampa real estate companies before being hired at Lincoln Property Group, a Dallas-based real estate group with partners in Florida (Keefe 1995). When Lincoln sold off its properties in 1986, Hogan chose to stay in the area and formed his own development company, The Hogan Group, in that same year. In 1990, Hogan married Rhonda Rasmussen, who was a partner in New Yorkbased Tishman Speyer Properties that managed several office spaces throughout South Florida (Valente 1990). By 1993, Hogan resurfaced as a real estate executive trying to form a REIT to buy office spaces, warehouses, and retail space. However, the REIT bubble burst mere weeks before Hogan went public with his and he abandoned the plan. Prior to the merger with Burt, Hogan had projects in progress as far away as Miami (Keefe 1995).

Jim Burt II had been in the real estate business his whole life. He got his start working with his father who had developed Old Hyde Park, the commercial area in the oldest part of Tampa adjacent to Tampa Bay (Huettel 1996). When he and Hogan merged in September 1995, they were able to get Robin Bishop to join them from Cushman \& Wakefield, a commercial real estate brokerage firm, and start the Hogan-BurtBishop brokerage department (Keefe 1995). They ended up owning, developing, and managing over five million square feet of commercial real estate space (Gruss 1995). Hogan-Burt split amicably in September 1998 as construction on the 220,000 square foot Channelside at Garrison Seaport project began (Simanoff 1998). Burt wanted to step back and evaluate options. He later noted:

We have found that the credit crunch of last fall [1998] only affected a certain segment of the investors out there. Though the REITs (real estate investment trusts) have slowed down in their activity, many of the traditional investors are very active, like insurance companies, pension funds. The terms may be tougher investors are looking for a greater return for their risk - but we haven't seen problems in getting money for the right kind of deal. (Parks 1999)

Hogan then established a $\$ 300$ million line of credit from Credit Suisse First Boston and formed the Hogan Group, Inc. with projects in other parts of the Southeast that involved buying, developing, and managing office space (Parks 1998). Hogan-Burt had about $\$ 60$ million in assets but Hogan's goal after restructuring was to reach the $\$ 1$ billion mark within five years. The Channelside opening was set back to February 2001 due to complications with designs related to changing ownership of the movie theatre occupants. In April of that year the Hogan Group called in CB Richard Ellis, based in Los Angeles, to assume leasing duties on behalf of Hogan. The former leased and managed commercial property throughout the world (Cronan 2001). CB Richard Ellis replaced the Hogan Group in 2003 as property manager.

After pouring about $\$ 49$-million into building the complex, in January 2005 ORIX Real Estate Equities contracted with Rockwood Realty Associates, a New 
York real estate investment banker to sell the complex. Although Regal Theaters had gone bankrupt, Channelside was 80 percent leased and had nine restaurants in operation. And there was optimism for the sale since

[f]oreign and domestic institutional investors flush with cash have been bidding up Florida shopping center prices. Most in demand are properties serving a growing population center. Developers are eager to cash out so they can get on to their next project (Albright 2005).

\section{Stage II - 2005-2014: Ashkenazy Ownership}

Ashkenazy Acquisition Corporation (AAC), led by New York real estate magnate Ben Ashkenazy, bought the property for an undisclosed amount in March 2005 (Albright 2005). The Port Authority, which still owned the land, held veto authority over the transaction but did vote to transfer the 40-year lease from the previous owner, ORIX, to Ashkenazy (Behnken 2005). Ashkenazy financed the purchase with a \$27 million loan from Anglo Irish Bank of Ireland. According to a New York Times interview with Michael Alpert, vice president of AAC, about half of the seven to ten properties that the company acquired each year were with an outside partner. AAC focused on long-term acquisitions which it acquired, improved, and held until the value appreciated (Alpert 2012). Deals were financed by a combination of loans, outside partners, and interest from the company's own investments.

Ireland was the first of the EU member states to be drawn into the 2007 sub-prime mortgage crisis. By the end of 2008 the Irish economy was in recession and in 2011 the Fianna Fail/Green Party coalition fell in the general election to the Fine Gael/Labour Party coalition. As the Irish real estate market and GNP collapsed, the government nationalized the two largest banks involved in real estate loans. The Anglo Irish bank dealt mainly in business and commercial banking. It lent heavily to builders and property developers. In December 2008, the government announced plans to inject 1.5 billion Euros into the bank. This amounted to about three-quarters of a stake in the bank and resulted in its being nationalized in January 2009. In November the government established the National Asset Management Agency (NAMA) to buy "toxic loans" of various financial institutions. In the first half of 2009, the government injected over 12 billion Euros into the bank.
The banking crisis in Ireland expanded during 2010. The Port Authority filed suit to evict the Channelside owners in Hillsborough County Circuit Court for letting the property deteriorate and in March the Anglo Irish Bank sued Ashkenazy's local company, Channelside Bay Mall LLC, to foreclose the Channelside property. The bank claimed that the local company had not made a payment on the loan in over one year and still owed the bank \$26.1 million (Huettel 2011). The bank won the suit and in September the court appointed Chuck Taylor, an experienced Tampa real estate manager, to run Channelside. In April 2011 Taylor announced that CB Richard Ellis Estate was assigned to sell the property. Any buyer would have to be approved by the Tampa Bay Port Authority and Ashkenazy's contract was still enforceable and had a Right of First Refusal provision in it.

The Irish government's liabilities to cover the banking crisis had increased dramatically during 2010 . In March, the Anglo Irish Bank reported the largest loss in Irish corporate history. In August the European Commission approved a temporary grant of 10 billion Euros to the bank to meet its capital reserve requirements. The Irish Nationwide Building Society which, like the Anglo Irish Bank, had played a key role in risky lending practices that led to the banking crisis was effectively nationalized at that time after receiving a 5.4 billion Euros bailout. By late summer, the Irish Bank losses "were so large that they led to an erosion of confidence in the banking system and the wider economy" (FitzGerald and Kearny 2011: 8). By November, the European Central Bank had successfully pressured the government to agree to a package of 35 billion Euros of loans with the EU/IMF to finance both government borrowing and recapitalizing the banking system. In July 2011 the Irish Bank Resolution Corporation (IBRC) was established as a court-mandated merger of the state-owned Anglo Irish Bank and Irish Nationwide Building Society. As the financial crisis continued in the U.S. and Ireland and spread to other parts of the European Union in 2011 and 2012, buyers for Channelside were hard to find. IBRC was in no position to improve or maintain the property beyond what was legally required. On 25 September 2012 the Channelside Cinemas closed. Stump's Supper Club and Howl at the Moon, both longtime tenants, also closed that month.

The Tampa Bay Lightning owner, Jeff Vinik, expressed interest in purchasing and reviving the property in 2012. Vinik had departed Fidelity Magellan Fund in 1996 after four years as its portfolio manager. 
While there, he had a solid track record of outperforming competitors until he moved out of technology stocks and into bonds in the fall of 1995 . He left Magellan, established Vinik Asset Management LP (VAM) hedge-fund and ran it aggressively for over fifteen years. During that time and through his Tampa Bay Sports and Entertainment LLC, Vinik purchased the Lightning ice hockey team in 2010 for $\$ 110$ million. Its home is the publicly owned Amalie Arena located in the District. In June 2013 Vinik gave his VAM clients \$6 billion of their money back. VAM had been on the decline after poorly timed bets on gold and the direction of stocks. The bad timing occurred when Vinik shifted from stock tracking to analysis of "macroeconomic trends and risk management". After moving to Tampa, Vinik continued to be involved in growth-oriented opportunities and stocks and bonds investments by playing to his skills in "macro analysis, industry selection and risk management." (Weiss and Kishan 2013). The Port Authority supported Vinik's interest in Channelside but his group abruptly pulled out of a deal on 22 October 2012 after IBRC noted that the contract with Ashkenazy included a "Right of First Refusal" provision (Thalji 2012b).

As the property continued to deteriorate, the Irish government passed legislation in February 2013 to liquidate IBRC and replace its promissory notes with bonds of an average maturity of 27 years. In April 2013 a new player surfaced with a bid to buy the Channelside Complex. Liberty Channelside LLC, an investment group run by two local developers, Santosh Govindaraju and Punit Shah, revealed they had been in negotiations with both TPA and IBRC. Their plans for the complex included offices, retail, and entertainment-not entirely different from the successful formula used to revive Centro Ybor, the development just north of Channelside in Ybor City (Thalji 2013c). However, negotiations between the Port and Liberty derailed when the Port demanded that Liberty place $\$ 10$ million (later revised to just $\$ 8$ million) in a joint escrow account to be used to improve the complex. Liberty was only willing to contribute $\$ 3.5$ million (originally $\$ 2$ million) to the account, citing concerns that they would be held hostage by their own money and the unorthodoxy of the deal. The Port's Board was upset over the lack of any concrete deal and what the Port viewed as Liberty dragging its feet in responding to requests for financial documents.

At its May 21 meeting, the Port voted unanimous approval of Hillsborough County Commissioner Sandra Murman's motion to reject Liberty's offer to buy the property - an offer IBRC had supported. Charles Klug, Deputy Port Director of Administration and Port Counsel, told the board that he had held several meetings with Liberty since the April 19 proposal and that "Liberty had been unwilling to make specific commitments concerning their long-term plans for the property."(Tampa Port Authority 2013:11). He stated that negotiations stalled when Liberty "would not commit to investing more than $\$ 2$ million in the facility...[so Port] staff could not recommend to the Board moving forward with the Liberty proposal...." (Tampa Port Authority 2013:12).

The Board's vote brought allegations and the threat of legal action from Liberty that the Port was never serious about considering its proposal (Thalji 2013e). IBRC also charged the Port with foul play, stating that it believed that the Port "did not act in good faith", made unreasonable escrow demands, and had a vote that was not scheduled in advance and without notifying IBRC or Liberty. The bank noted that in its two and a half years of trying to sell the property, Liberty was the first party to have had an escrow demand thrust on it. Jeff Vinik, whom many believed the Port favored to buy Channelside, did not have a similar demand placed on him when he was in negotiations to buy the property in 2012 (Thalji 2013d).

During the second half of 2013, TPA expressed continued willingness to explore any option to resolve the Channelside debacle. Since the Port and IBRC could not reach agreement, in July the Port Authority began exploring the option of the Port itself buying the Channelside complex. The Port's newly appointed chairman, Steven Swindal, said that the possibility of a Port-buyout was largely dependent on what price the Port could agree on with IBRC (Thajli and Hobson 2013). Estimates of the complex's worth ranged from its last appraisal of $\$ 12$ million to the $\$ 18-26$ million the Port believed the nearly deserted property was worth. However, the Port's Governing Board was far from unanimous in its enthusiasm for working with the bank on a deal. There were many unknowns, such as how the Port Authority would fare at managing the property until it could find a buyer and the uncertain status of the ongoing lawsuit to evict the bank from ownership of the property. Any deal reached on the ownership of the property would have to settle both questions simultaneously while also exposing the Port to the greater risk of actually owning the entire property instead of just being the landlord (Thalji 2013h). While the Port was exploring the option of buying the property itself, it also authorized Chairman Swindal to not wait 
for IBRC to find a buyer but instead to itself look for other possible buyers it could present to IBRC. Both the Port and the Bank had to agree on a change of ownership and the Port appeared to favor Vinik while IBRC favored Liberty Group (Thalji 2013f).

In September 2013 the Port announced that it would buy the property for $\$ 5.75$ million, an amount that was considerably lower than any of the complex's appraisals. The deal may have been spurred by IBRC's August 28 filing of a Chapter 15 bankruptcy petition in Delaware for its American assets of over $\$ 1$ billion (Milford and Brennan 2013). The Bank's ongoing lawsuits in both Federal bankruptcy court and the Hillsborough circuit court complicated the deal as judges for both courts had to approve the Port's offer (Thalji 2013g). The bankruptcy petition put a temporary halt to all litigation regarding the Banks' American properties while the Bank's investigators took time to examine the Bank's assets. The delay meant that it was unlikely the deal would be approved before the initial deadline of November 30. Regardless, Port officials remained optimistic and were confident that both sides would agree to an extension of the offer. Some at the Port were concerned that if the federal bankruptcy judge granted the Chapter 15 petition, then the Port's bid to buy would have extra hoops to jump through before it could be finalized, including a twoweek period when the court would be open to objections of any creditors with claims on the property.

When the Port made its offer to purchase, Liberty Channelside Group requested that their legal counsel be sent copies of all proceedings regarding the federal bankruptcy case. This raised some concerns at the Port, but staff there remained confident that Liberty would not have a legitimate claim to complicate the deal beyond delaying it in court (Thalji 2013j). But in December Liberty sued both the Port and IBRC in federal court to stop the sale. The suit "alleged that the port sabotaged their deal so the port could buy Channelside and take advantage of the low price that Liberty had negotiated with the bank." (Thalji 2014a). In early February 2014 Liberty lawyers filed documents in the bankruptcy court requesting that several Port officials be deposed about Port efforts to buy the property. Depositions from Murman, Klug, and other Port staff were to be given on February 11 (Thalji 2014b)

On February 18, 2014 U.S. Bankruptcy Judge Christopher Sontchi rejected the Port Authority's offer to purchase Channelside from IBRC for $\$ 5.75$ million.
The bankruptcy filing required the Judge's approval for the sale. Instead "he told the [IBRC] liquidators to get more money from Channelside" than what the Port had offered and ordered that an auction of the property be held. In fact, the Liberty group had appeared in Sontchi's court February 14 with a guaranteed check for $\$ 7$ million (Thalji 2014c). In making his ruling, Sontchi gave some credence to Govindaraju's claims about how a political website had portrayed his remarks during negotiations with Port authorities in May by stating that "Failure to consent (to the sale), at least based on some sort of ethnic or religious prejudice, is not in good faith." Govindaraju is a practicing Hindu who grew up in Tampa where he attended high school before going to the University of Pennsylvania, then becoming a Wall Street trader before becoming CEO of Convergent Capital Partners LLC in Tampa. The judge did not rule on whether TPA could cancel any deal the bank supported to sell Channelside so he did not settle the impasse between TPA and IBRC.

In early March, various members of the Port's Governing Board expressed willingness for the Port to pay $\$ 7$ million or more for Channelside. Patrick Allman, a member of the board and General Manager of Odyssey Manufacturing Company, the largest industrial supplier of sodium hypochlorite in Florida imported through the Port of Tampa, stated that TPA was working with IBRC on a legally binding purchase agreement. In April Judge Sontchi dismissed Liberty's claims for damages but also refused to accept the Port's claims that it rather than IBRC had sole authority over the Channelside lease and therefore had the right to file for bankruptcy in his court. He ruled there was sufficient evidence that the Port had acted in bad faith. Liberty was given 28 days to refile more evidence related to its "tortuous interference" claims for damages because the Port had acted based on racism and malice in rejecting its bid (Thalji 2014d and 2014e).

The bankruptcy judge had allowed IBRC to use its own rather than the court's auction procedures. Bids were due July 2. The Bank assigned special liquidators to oversee and then select one of the bids. Judge Sontchi would then rule on the winning bid at a July 15 hearing. The process was highly secretive and once again challenged by Liberty (Talji 2014f). During this period, a report was submitted itemizing all the work that had to be done to maintain the Channelside property. Various bidders expressed interest in the property. IBRC requested permission from the judge to walk away from the property if the auction was not 
successful in bringing an acceptable bid to him. The bank was handling more than $\$ 34$ billion of distressed assets around the world that had been previously held by failed Irish banks.

\section{Stage III - 2014-2015: Vinik Ownership}

In later June, Vinik reappeared with a bid of $\$ 7.1$ million for Channelside through his LLC, CBP Development. Liberty chose not to submit a bid, claiming that the auction process itself was not legal. In addition, Vinik offered a $\$ 10$ million letter of credit to upgrade and maintain the property as documented in the report submitted by the company IBRC had contracted with to manage the property. TPA also submitted a bid of $\$ 5.75$ million for the property and $\$ 3.5$ million for the loan on it (Talji 2014g). Local newspapers were quick to endorse the Vinik bid and TPA hailed his proposal even before the July 2 deadline. The auction was conducted in New York on July 2. Vinik's bid was accepted. On July 8 Liberty filed suit, alleging that the top players - IBRC, the Port, and CBP Development - had colluded to hand the property over to Vinik's LLC. The Port responded immediately by saying that it was Liberty that sabotaged the process by not submitting a bid.

After the July 15 hearing but before Judge Soncthi issued his ruling, the Port, Liberty and CBP Development LLC reached a settlement that removed any legal claims. Soncthi approved the settlement that gave Vinik effective control of the property. The Port agreed to pay the liquidators $\$ 1.9$ million to purchase the Channelside mortgage. Vinik paid $\$ 7.1$ million for the lease on the property, negotiated "a settlement of pending litigation relating to the Lease Assets," and obtained "rights to certain plans" that Liberty had for the site. All sides also agreed to pay their own attorney's fees. (Mullins 2014)

In September, Vinik's buying spree escalated. Cascade Investment LLC, controlled by Microsoft founder, Bill Gates, agreed to help finance Vinik's 24 acre project for a "massive entertainment, office, residential and retail district around the Amalie Arena. (Thalji, Martin, and Danielson 2014). In October, his group bought the Tampa Marriott Waterside Hotel \& Marina for $\$ 199$ million. He also hired a team to lobby the Florida legislature for millions of dollars for a new downtown medical school for the University of South Florida in exchange for giving the university the land in his project zone on which to build. (Thalji and Danielson 2014; Danielson 2014a). After purchasing 4 acres of vacant land used for parking and adjacent to his other holdings in December, he unveiled a $\$ 1$ billion square footage plan for his properties: 1.1 million residential space; 375,000 hotel/meeting space; 330,000 for the USF medical school; 250,000 of retail; and 5,000 for parking (Thalji 2014h). A key piece of the proposal required approval from the Tampa City Council to reimburse Vinik for costs he would incur to rebuild roads, improve drainage and make other infrastructure upgrades to suit his redevelopment plan (Danielson 2014b).

Throughout 2015, Vinik built a coalition of support from the public and private sectors. In mid-January the Tampa City Council pledged $\$ 15$ million to reimburse Vinik for "public works improvements" (Danielson 2015a). In late February the State Board of Governors' supported that the University of South Florida pay $\$ 153$ million of state money and private donations to build a 12-story office tower/medical campus within Vinik's redevelopment project (Thalji 2015a). Seventeen million dollars of the state funds were included in the FY 2015-16 budget passed in June. At the end of February, Vinik asked Hillsborough County to split $\$ 25$ million with him to improve the county-owned Amalie Arena structure (Peterson 2015). In March he hired two leaders of the "new urbanists" movement, Jeff Speck and David Dixon, to submit a proposal for how to make his 40 acres into a livable walking space for "millennials and empty nesters" (Thalji 2015b). In April the Museum of Science and Industry (MOSI), located several miles north of Vinik's holdings, came under renewed scrutiny for its management. What was new, however, was the conjecture that MOSI might be more profitable if it moved to the Channelside area, a move Vinik endorsed (Mullins 2015). The museum, a non-profit organization subsidized by both Hillsborough County and the City of Tampa, had been struggling financially for several years. Also in April and again in late July Vinik gave $\$ 100,000$ to "Let's Get to Work", a political fundraising committee run by Florida's governor, Rick Scott (Wallace 2015). In August, TPA unveiled a \$1.7 billion water front project adjacent to Vinik's holdings. The proposal was to convert 45 acres of asphalt into a new cruise ship terminal, more residential, hotel, and retail outlets, and a new marina (Danielson 2015c). That month another of the Tampa Mayor's top aides left to become director of communications for Vinik's Strategic Property Partners LLC (Danielson 2015d). By the end of 2015 Vinik had amassed a remarkable degree of support from the state, county and city. He also brought together a set of investors and launched a 
plan supported by urban academics to increase the density of 40 acres of built-environment adjacent to the channels running from Tampa to the Gulf of Mexico. He had the endorsement of the major two newspapers in the Tampa Bay Area, both of which wrote occasional editorials supporting his acquisitions and plans.

\section{Analysis}

Three configurations of class relations occurred between 1995 and 2015. The first two arrangements (Diagrams 1 and 2) led by ORIX and then by Ashkenazy were unsuccessful attempts to develop a profitable Channelside commercial property. The third arrangement (Diagram 3) led by Vinik expanded in scale and scope and promised to be profitable. The reasons for failure in the first two arrangements differ yet share an inability to construct successful relations with experts and local elites.

In the first arrangement, none of the fractions of the TCC exhibited the kind of unity needed to accumulate wealth. Orix Real Estate Equities out of Chicago may never have intended to hold on to the property long- term. In early 2005 it turned to a New York realtor to sell the Channelside Plaza. Orix did not combine the necessary technical expertise - real estate developers and property managers - to make the project a success. It hired a local development group that lacked stability and expertise. During its short-time in operation, Hogan-Burt contracted a Los Angeles firm to manage the property, took out a sizeable line of credit from a Boston-based bank, and went through its own internal restructuring. It was not able to establish a stable niche at the Plaza. Neither Orix nor Hogan-Burt had the kind of linkages with the TPA or other local political leaders that could have sustained the project.

The sale of the property to Ashkenazy Acquisition Corporation (AAC) in 2005 re-centered TCC relations (Diagram 2) in New York. AAC established the Channelside Bay Mall LLC to hold the lease on the property. The purchase of the Plaza was financed through a loan from the Anglo Irish Bank of Ireland, thereby linking real estate market finances in Europe and the United States. Three years after the purchase, relations between TPA and

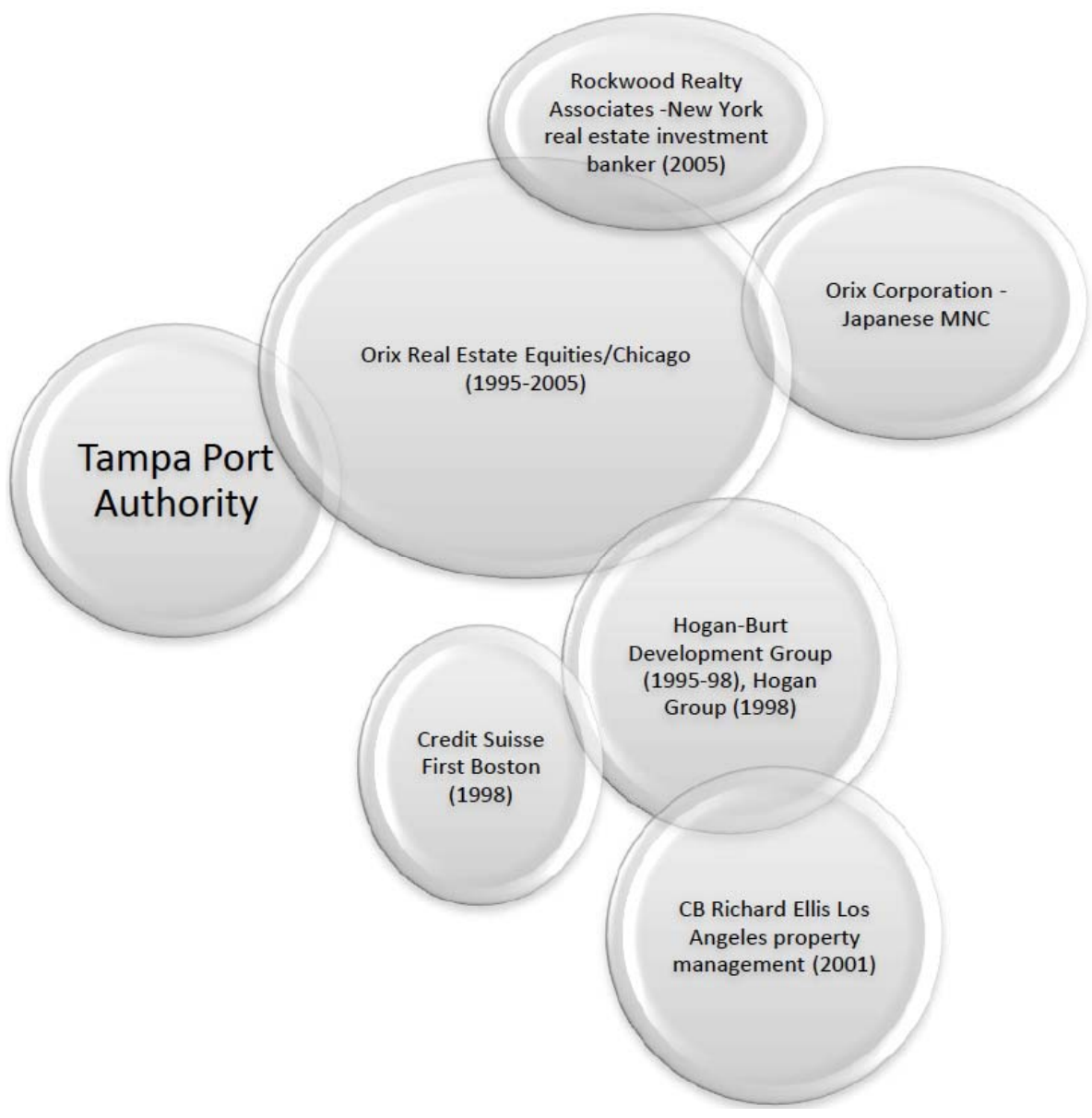

Diagram 1: Orix-Centered Ownership: 1998-2005. 


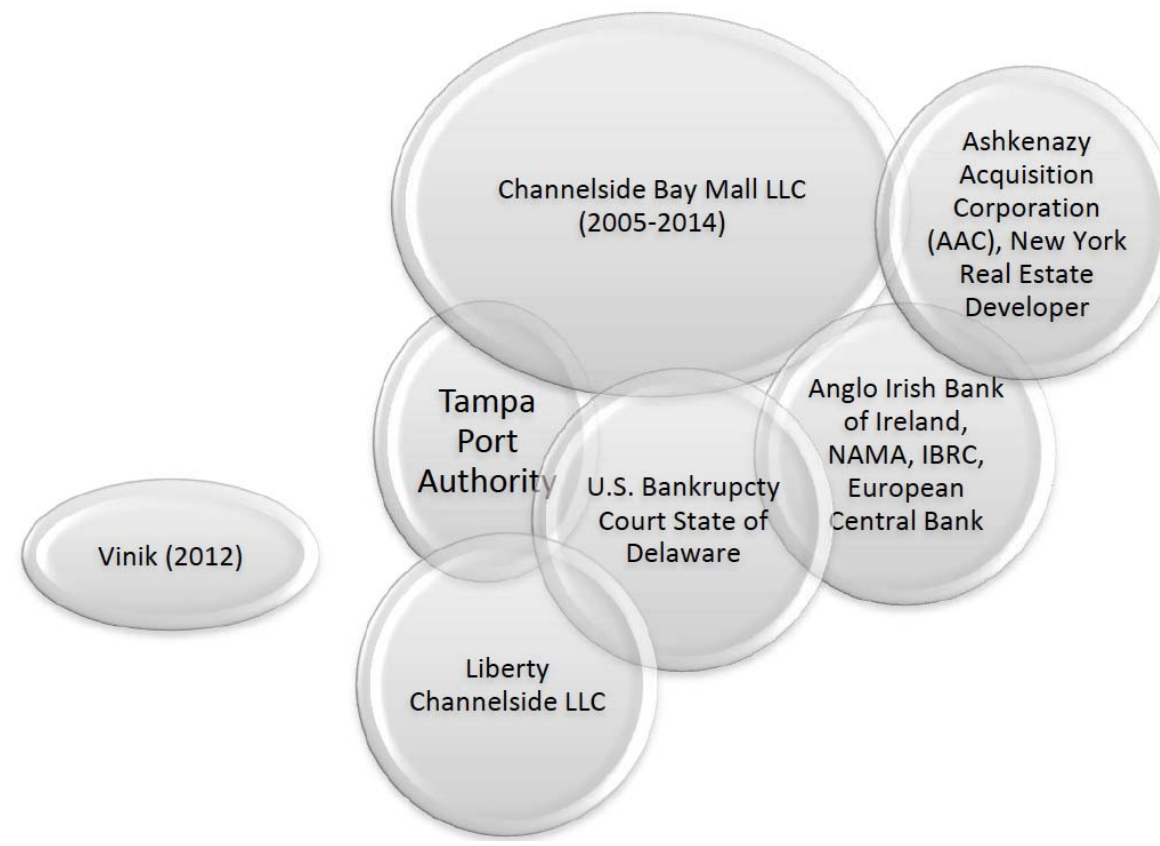

Diagram 2: Ashkenazy-Centered Ownership: 2005-2014.

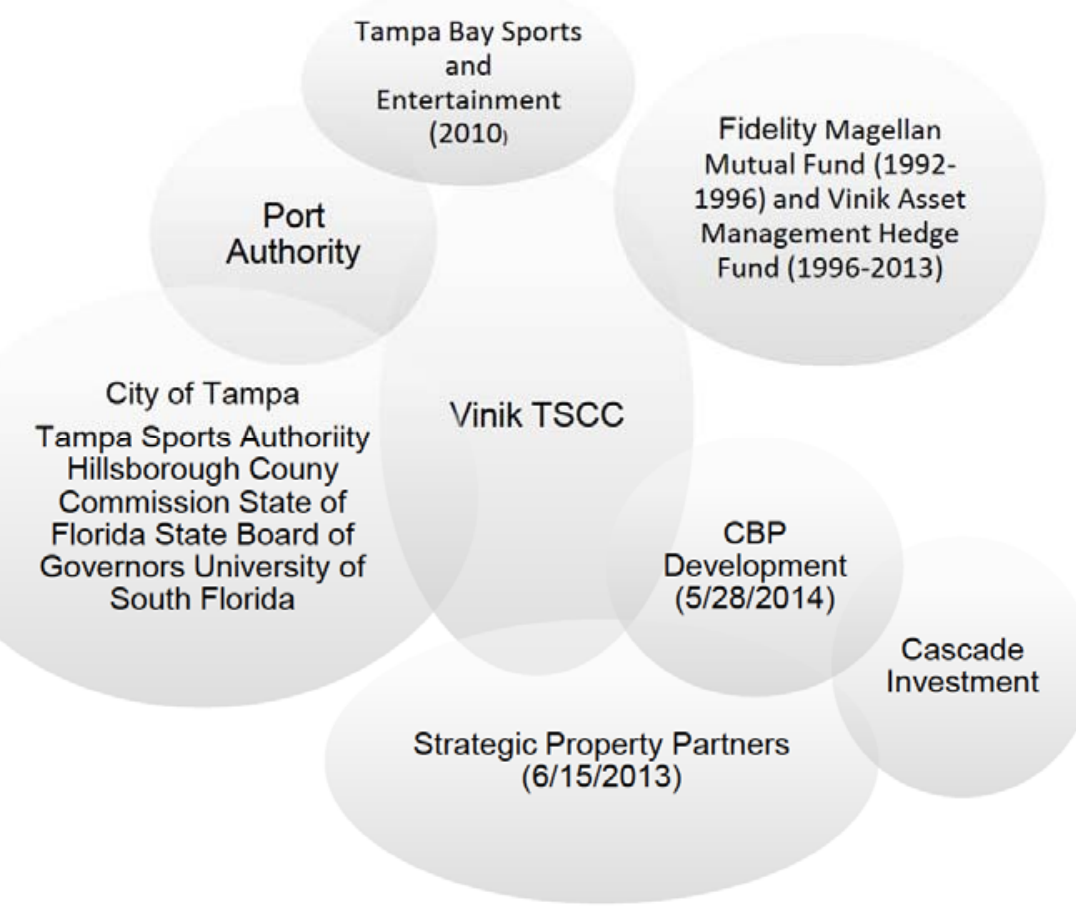

Diagram 3: Vinik-Centered Ownership: 2014-2015.

Channelside LLC began to deteriorate. TPA had signed a lease that ran through 2036 with options for 40 more years but by 2010 it took the LLC to court, suing it for over $\$ 330,000$ in rent and late fees, violations of fire code and allowing the complex to lapse into disrepair. Conflict escalated among all the fractions as more players entered to bid for a deteriorating property. From 2010 through the final decision of the Bankruptcy Court to accept the Vinik proposal in 2014, investor infighting was fueled by an Irish banking system in collapse and the inability of the public sector to mediate the conflict. Irreconcilable differences permeated the respective circuits of capital: public and semi-public institutions in the United States and Europe at multiple scales (i.e., Tampa Port Authority, Irish Bank Resolution Corporation (IBRC), Irish Government, European 
Union, U.S. Bankruptcy Court) and real estate investment firms and management companies (i.e. Ashkenazy Acquisition Corporation, Liberty Channelside LCC, and CBP Development LLC). Multiple elites had various financial stakes in the project at a time when financial markets and systems throughout the world were reeling from the sub-prime mortgage crisis. Only a court mandate could resolve the situation.

After the court accepted Jeff Vinik's bid to purchase the Plaza in early July 2014, Vinik established a transcalar network of experts and political elites - a Transcalar Capitalist Class (TSCC) tailored to meet his particular goals (see Diagram 3). This network is distinct in several respects. First, the scope of the commercial development project expanded significantly - from Vinik's ownership of Channelside Plaza (\#1 on Map 2) to over 40 acres in the Channelside District by the end of 2015. Second, the critical local relations have been with the public sector. Vinik's 40 acre development project won the support at all political elites at multiple institutional levels within Florida: local support from the Mayor and City Council of Tampa, the Hillsborough County Commission and Manager, the state's University of South Florida in Tampa Bay, the Governor's Office, the State's University System Board of Governors, and the State Legislature. In addition, he received several million dollars of public funds to supplement his $\$ 2$ billion commitment to convert the acreage into a "mini-city" within dowtown Tampa.

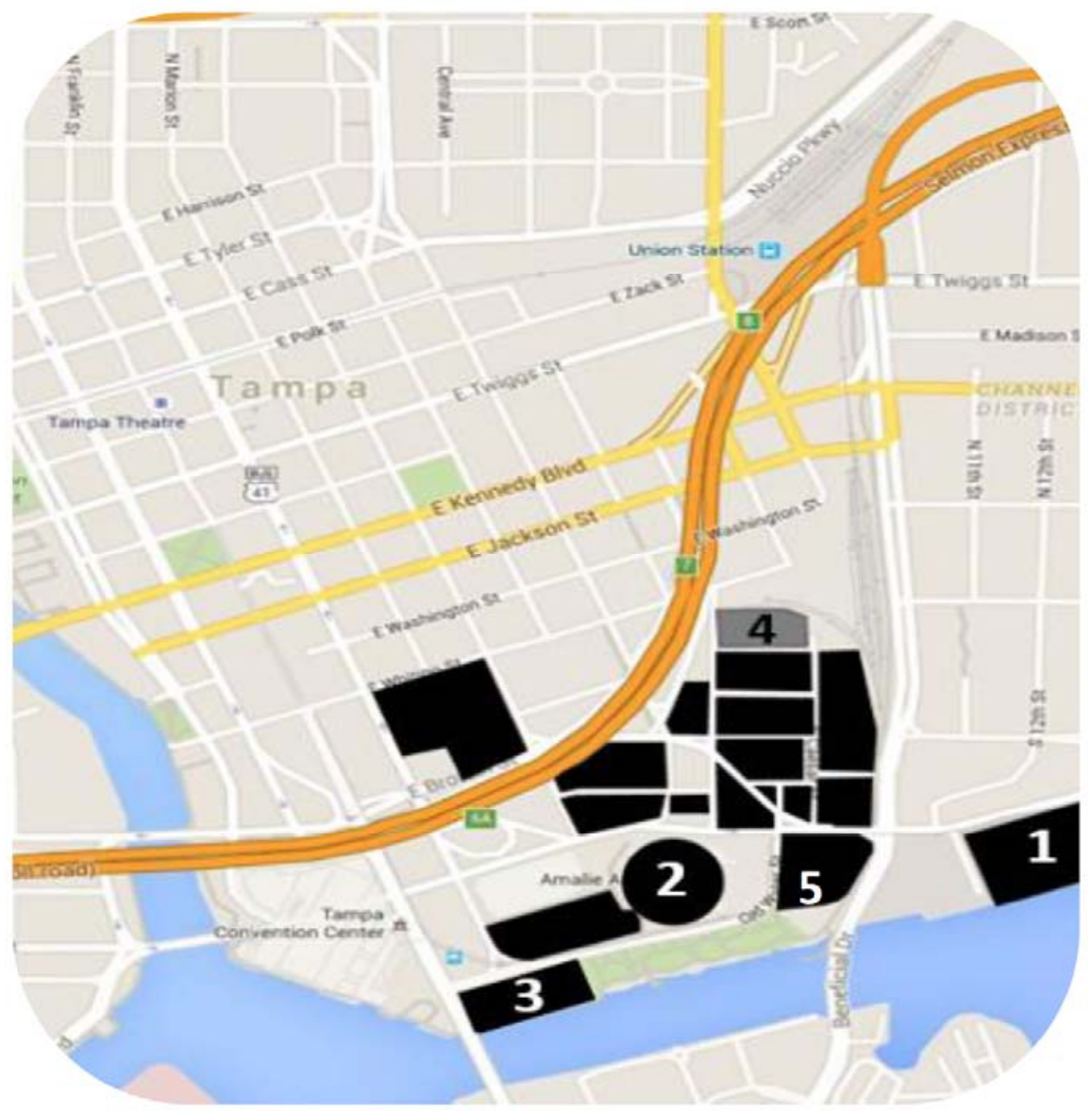

Map 2: Vinik-owned or controlled areas in downtown Tampa.

Source: https://www.google.com/maps/d/viewer?hl=en\&mid=197S1Q6z4InEtX5WSx-6LCNyQVdw

1=Channelside Bay Plaza - CBP Development purchase for \$7.1 million 07/21/2014

$2=$ Amalie Arena - Vinik group purchase of Tampa Bay Lightning for $\$ 110$ million 02/05/2010

3=Tampa Marriot Waterside Hotel - CBP Development purchase for \$199 million 10/02/2014

4=Flour Mill owned by ConAgra;

$5=$ USF Medical School and Heart Health Institute for \$153 million 12/08/2015 (dedication)

Other =Areas in black not numbered are Vinik-owned or controlled areas, either parking lots or undeveloped land 
Political support was reinforced by editorial praise from the local media. No investigative reporting was published on projected environmental, labor, or income equalizing impacts from the development plan.

Third, Vinik has a complex and opaque financial investment network. He formed the CBP Development LLC in advance of submitting a bid to the Bankruptcy Court but his financial network began in the 1990s when he managed the Fidelity Magellan Fund. Since that time, transcalar finance capital flows through his various LLCs - Vinik Tampa Employees; Vinik Family Office; Nah Sarasota; Jaydak; Vinik Family Investments; Lightning Real Estate Investment Group; Channelside Cumberland Properties, and Cumberland Jefferson Properties - are not readily accessible. Most recently, he established Strategic Property Partners to oversee development of the 40 acres and a financial partnership with Cascade Investment, Bill Gates' LLC, to finance 24 of the 40 acres.

\section{CONCLUSION}

Capitalist class conflict can occur in the most innocuous of settings like Tampa's downtown development project in the Channelside District. The Channelside Plaza venture demonstrates that the interstate capitalist class divisions Robinson (2012) noted are not limited to tensions among elites in countries with different levels of development. The commercial project also points to further evidence of the inter-capitalist competition Bello (2006) identified between the European Union and the United States in the early 21 st century. The Channelside case was not about interstate rivalries but rather intra-class conflicts in the OECD over real estate development at a time when the capitalist accumulation process cycled through the sub-prime mortgage crisis. The systemic crisis brought on by unregulated financial markets underscores that intra-class unity is precarious. The Ashkenazy period (Diagram 2) coincided with a generalized crisis in the market. In this instance, class solidarity gave way to self interest in maintaining wealth or mitigating losses. Elites could not resolve the conflicts among themselves for a three year period that linked the lawsuit against Channelside Bay Mall with the banking crisis in Ireland, the European Union bailout and the resolution by the United States Bankruptcy Court.

Owners of commercial real estate projects can be remote from the project site: Orix in Chicago and Ashkenazy in New York. Financing ownership of such projects can be even more remote and difficult to document. From an investor's perspective real estate is abstracted from its place. Location is less salient than financial risk. In their analysis of Swiss pensions funds, Corpataux et al. (2009) suggested that pension fund investments in any part of the world could find their way to commercial real estate projects located anywhere in the world. Halbert and Rouanet (2013) underscored the need to overcome "foreign" investor fear by building transcalar territorial networks. But when the scalar connection between land and ownership is "severed", what does "foreign" mean? From an investor perspective, land is globalized and, as abstracted finance becomes more mobile, land's ownership is abstracted from place.

Who are the investors in the current Channelside development project? Answering this is a challenge since investor identity can be masked by abstract pools of finance capital that could underpin real estate deals. Consider millions of small investors whose savings flow into hedge funds, mutual funds, and REITS. Funnel property ownerships through multiple limited liability corporations and partnerships to diversify risk and hide liability. Place these legal corporations at "offshore" sights in former British colonies or the states of Delaware and Montana in the United States. A central shortcoming of this exploratory study leaves unanswered how the three owners of ChannelsideORIX, Ashkenazy, and Vinik - financed all of their operations in Tampa. Given the scope and scale of his development project and the role the public sector in it, further investigation of Vinik's sources of funding holds particular promise for documenting the role financial markets play in creating harmony or discord in intraclass relations. Bill Gates' funding commitment to the project may be the tip of a more widespread scalar involvement from the financial fraction. Research avenues to pursue include Vinik's work with Fidelity Magellan's mutual fund as well as his own hedge-fund and the LLCs and LLPs he has established.

Wood's (2004) research on Columbus, Ohio found that local relations matter in successful real estate projects. Halbert and Rouanet (2013) also found that elite relations are significant in real estate development outcomes. Vinik's success in Tampa appears to support the findings documented in their studies. TPA tried to upgrade the use and increase the value of the land surrounding the Port to enhance the public's (local and cruise ship passenger) waterside experience. That was its stated goal. As a semi-public entity, it leveraged its position as landowner to initiate the Channelside idea. Nevertheless, its behavior destabilized the 
project. In fact, the bankruptcy judge in Delaware threw out its offer in 2014 to buy the development at under market value. However when Vinik's bid was approved, public sector support became universal overnight. The city, the county, semi-public agencies, and state leaders praised Vinik's vision and offered millions of dollars in public funds to implement the project. Vinik's wealth and local reputation may well have created a unity of purpose within the TSCC. The durability of that unity, however, warrants further exploration by documenting the connection between the transcalar sources financing the project and local relations among the various fractions of the capitalist class, especially those involving the public sector.

\section{ACKNOWLEDGEMENTS}

I would like to extend my gratitude to the anonymous reviewers for their helpful recommendations, to Adriana Padilla for her help with the diagrams and maps, and to Anthony Cilluffo for his research assistance.

\section{REFERENCES}

Albright, Mark. 2005. "Channelside goes on Market," St. Petersburg Times (FL) 25 January.

Albright, Mark. 2005. "Owner: Complex is on upswing." St. Petersburg Times (FL) 16 March. South Pinellas, Business: 1D. News Bank. Web. 31 Oct. 2012.

Albright, Mark. 2006 "Two partners flee Centro Ybor." St. Petersburg Times (FL) 4 January.

Behnken, Shannon. 2005. "Bail-Out Check Headed To Mall - District Upgrade Fund Raided For Centro Ybor." Tampa Tribune, 14 May.

Behnken, Shannon. "Investor Ready To Buy Channelside Complex." Tampa Tribune, 17 Mar. 2005

Bello, Walden. 2006. "The Capitalist Conjuncture: over-accumulation, financial crises, and the retreat from globalization," Third World Quarterly 27:8:1345-1367. http://dx.doi.org/10.1080/01436590601027222

Bieri, David. 2013. "Form Follow function: On the Interaction between Real Estate Finance and Urban Spatial Structure," Critical Productive, 2:1;1-18.

Borras Jr., Santurnino, Ruth Hall, Ian Scoones, Ben White, and Wendy Wolford, 2011. "Towards a better understanding of global land grabbing: an editorial introduction". Journal of Peasant Studies 38 (2): 209 http://dx.doi.org/10.1080/03066150.2011.559005

City of Tampa. 2012. "Channel District History." http://www.tampagov.net/dept_economic_and_urban_develo pment/programs and services/Community redevelopment areas/Channel_District/History.asp

Corpataux, Jose, Olivier Crevoisier, and Thierry Theurillat. 2009. "The Expansion of the Finance Industry and Its Impact on the Economy: A Territorial Approach Based on Swiss Pension Funds". Economic Geography 85 (3): 313-334. http://dx.doi.org/10.1111/j.1944-8287.2009.01035.x

Danielson, Richard. 2014a. "Vinik hires lobbying team," Tampa Bay Times 15 October.
Danielson, Richard. 2014b. "Vinik funding to get a look," Tampa Bay Times, 27 December.

Danielson, Richard. 2015a. "Vinik's project gets \$15 million," Tampa Bay Times, 15 January.

Danielson, Richard. 2015b. "Port Plans \$1.7B urban waterfront," Tampa Bay Times, 14 August.

Danielson, Richard. 2015c. "Buckhorn aide exits to work for Vinik," Tampa Bay Times, 15 August.

Editorial. 2010. "Channelside Needs Fixing, Fast." The Tampa Bay Times, 27 September.

Cronan, Carl. 2001. "Channelside calls in the big guns," Tampa Bay Business Journal, 4 April.

Fitzgerald, Barbara. 2012. "Public debt for Tampa increases six fold since '83." Tampa Tribune 19 September.

FitzGerald, John and Ide Kearney. 2011. "Irish Government debt and Implied Debt Dynamics: 2011-2015," Dublin: Economic and Social Research Institute.

Froelich, Janis. 2005. "lorio Lauded At Towers Groundbreaking Mayor's Support Led to Rezoning Success." Tampa Tribune, 22 January.

Gotham, Kevin. 2006. "The Secondary Circuit of Capital Reconsidered: Globalization and the U.S. Real Estate Sector," The American Journal of Sociology, 112:1:231-75. http://dx.doi.org/10.1086/502695

Gruss, Jean. 1995. "Real estate companies Hogan, Burt to merge." The Tampa Tribune 7 September.

Halbert, Ludovic and Hortense Rouanet. 2013. "Filtering Risk Away: Global Finance Capital, Transcalar Territorial Networks and the (Un)Making of city-Regions: An Analysis of Business Property Development in Bangalore, India," Regional Studies.

http:///dx.doi.org/10/1080/00343404.2013.779658

Harrington, Jeff. 2013. "Vinik Has Big Dream For Tampa." Tampa Bay Times (FL) 10 May.

Harvey, David. 1978. "The Urban Process Under Capitalism; A Gamework for Analysis," International Journal of Urban and Regional Research 2:101-131. http://dx.doi.org/10.1111/j.1468-2427.1978.tb00738.x

Huettel, Steve. 1996a. "Aquarium Bailout Imperils Projects." The Tampa Tribune 16 April.

Huettel, Steve. 1996b. "Mike Hogan and Jim Burt - Property developers." The Tampa Tribune 29 December.

Huettel, Steve. 2011. "Channelside Bay Plaza Being Prepared for Sale." St. Petersburg Times (FL) 20 April.

Keefe, Robert. 1995. "He sees time for a change - again." St. Petersburg Times 26 December.

Kritzer, Ashley. 2014. "Challenges ahead for Channelside Redevelopment," Tampa Bay Busines Journal, 4 August.

Lefebvre, Henri. (1970). 2003. The Urban Revolution. Minneapolis: University of Minnesota Press.

Lengell, Sean. 2005. "The Center - Of Controversy." Tampa Tribune, 15 October.

Mariano, Vivian. 2012. "Michael S. Alpert." The New York Times, 28 February.

Margulis, Matias, Nora McKeon, and Saturnino Borras, Jr. 2013 Land Grabbing and Global Governance: Special Issue, Globalizations, 10:1 http://dx.doi.org/10.1080/14747731.2013.764151

Meacham, Andrew and Bill Coats. 2008. "Tracking a Sensible Vision." St. Petersburg Times, 16 May.

Milford, Phiilip. and Joe Brennan. 2013. "IBRC files bankruptcy petition in US," Irish Examiner. 28 August.

Mullins, Richard. 2014. "Settlement Approved, Vinik takes control of Channelside," Tampa Tribune 21 July. 
Mullins, Richard. 2015. "MOSI may move to Vinik's Channelside Project," 25 April.

Nipps, Emily. 2008. "Angst Towers Over Some Buyers." St. Petersburg Times, 29 February.

Parks, Kyle. 1998. "Developers Hogan and Burt split, St. Petersburg Times, September 25. http://www.sptimes.com/Business/ 92598/Developers_Hogan_and_.html

Parks, Kyle. 1999. "Jim Burt \& Jim Schroeder - Developers see steady growth in bay area." St. Petersburg Times, August 2.

Peterson, Zack. 2015. "Vinik asks county to pitch in for arena redo," Tampa Bay Times, 28 February.

Puente, Mark. 2012. "Lightning Owner Jeff Vinik Emerges as Frontrunner to Buy Channelside Bay Plaza." Tampa Bay Times 22 May,

Robinson, William. 2004. A Theory of Global Capitalism: Production, Class, and State in a Transnational World, Baltimore: Johns Hopkins University Press. http://dx.doi.org/10.1177/0896920511411592

Robinson, William. 2012. "Global Capitalism theory and the Emergence of Transnational Elites, "Critical Sociology, 38:349-63.

Romano, John. 2012. "Tampa, Meet Your New Neighbor." Tampa Bay Times, 19 April.

Rulli, Maria., Antonio Saviori, and Paolo D’Ordorico. “Global land and water grabbing," PNAS Early Edition, www.pnas.org/cgi/doi/10.1073/pnas.1123163110.

Sassan, Saskia. 1991. The Global City: New York, London, Tokyo, Princeton: Princeton University Press.

Sassen, Saskia. 2013. "Land Grabs Today: Feeding the Disassembling of National Territory," Globalizations, 10:1:2546. http://dx.doi.org/10.1080/14747731.2013.760927

Shopes, Rich. 2006. "Authority - Gets Rent - From ConAgra." Tampa Tribune, The (FL) 31 July.

Sklair, Leslie. 1997. Capitalism and Development. New York: Routledge

Sklair, Leslie. 2002. "Democracy and the Transnational capitalist Class," The ANNALS of the American Academy of Political and Social Science, 581:144-57. http://dx.doi.org/10.1177/0002716202058001013

Stebbins, John. 1994. "Council boosts hotel - Members vote to support a bond issue if a study determines the project is feasible." The Tampa Tribune 3 June.

Struna, Jason. 2013. "Global Capitalism and Transnational Class Formation," Globalizations 10:5:651-657

Tampa Port Authority. 2013. "Boardbook: Monthly Business Meeting," June $18 \mathrm{http}: / /$ www.tampaport.com/userfiles/files/ June\%2018\%202013\%20Board\%20Meeting\%20Agenda.pdf

Thalji, Jamal. 2012a. "Channel District Idea Pivots on Flour Mill." Tampa Bay Times (FL) 16 October.

Thalji, Jamal. 2012b. "Vinik's Vision is on Hold." Tampa Bay Times (FL) 23 October.

Thalji, Jamal. 2013c. "Liberty Group unveils plans for Tampa's Channelside retail complex." Tampa Bay Times, 22 April

Thalji, Jamal. 2013d. "Port is Blasted for Deal Refusal." Tampa Bay Times (FL) 29 May. Pinellas, Local: 1B. News Bank. Web. 26 Jun. 2013.
Thalji, Jamal. 2013e. "Pair: Port Undercut Us." Tampa Bay Times (FL) 30 May.

Thalji, Jamal. 2013f. "Port Seeks Channelside Bids." Tampa Bay Times (FL) 21 August.

Thalji, Jamal. 2013g. "Port of Tampa Set to Buy Channelside Retail Complex For $\$ 5.75$ Million." Tampa Bay Times, 10 September.

Thalji, Jamal. 2013h. "Should Port Buy Channelside?" Tampa Bay Times (FL) 28 July.

Thalji, Jamal. 2013i. "Vinik Buys More Downtown Land." Tampa Bay Times (FL) 19 November.

Thalji, Jamal. 2013j. "Retail Site Sale Hung Up In Court." Tampa Bay Times (FL) 3 December.

Thalji, Jamal. 2014a. "Vetoed plaza buyer returns," Tampa Bay Times, 14 February.

Thalji, Jamal. 2014b. "Port Officials to be questioned," Tampa Bay Times, 8 February.

Thalji, Jamal. 2014c. "Channelside deal killed," Tampa Bay Times. 19 February.

Thalji, Jamal. 2014d. "Port still angling for mall," Tampa Bay Times, 1 March.

Thalji, Jamal. 2014e. "Some wins, a loss in Channelside war," 10 April.

Thalji, Jamal. 2014f. "Channelside auction outcome is near," 13 June.

Thalji, Jamal. 2014g. "Vinik renews interest in mall," 29 June.

Thalji, Jamal. 2014h. "Vinik unveils \$1B Tampa vision," 18 December.

Thalji, Jamal. 2015a. "New USF med school step closer," 20 February.

Thalji, Jamal. 2015b. "Urban Visionaries," Tampa Bay Times, 30 March.

Thalji, Jamal. and Will Hobson. 2013. "Chairman William 'Hoe' Brown resign from Tampa Port Authority Board," Tampa Bay Times, July 12.

Thalji, Jamal. and Richard Danielson. 2014. "Vinik buys the Marriott," 3 October.

Thalji, Jamal, Susan Martin, and Richard Danielson. 2014. "Gates Investing in Vinik's Vision," Tampa Bay Times, 26 September.

Valente, M. 1990. "Real estate pros plan new partnership." The Tampa Tribune 21 September.

Van der Pijl, Kees. 2005, "Feature Review," New Political Economy, 10:2: 273-77.

Wallace, Jeremy. 2015. "Vinik Scott's biggest donor," Tampa Bay Times, 24 July.

Weiss, Miles. And SaijelKishan. 2013. "Vinik to Shut Hedge-Fund Business to focus on Hockey Team," Bloomberg Business, 3 May.

Wood, Andrew. 2004. "The scalar transformation of the US commercial property-development industry: a cautionary note on the limits of globalization," Economic Geography, 80: 11940.

http://dx.doi.org/10.1111/j.1944-8287.2004.tb00304.x

\section{DOI: http://dx.doi.org/10.6000/1929-7092.2016.05.19}

(c) 2016 M. Mark Amen; Licensee Lifescience Global.

This is an open access article licensed under the terms of the Creative Commons Attribution Non-Commercial License (http://creativecommons.org/licenses/by-nc/3.0/) which permits unrestricted, non-commercial use, distribution and reproduction in any medium, provided the work is properly cited. 